LSP International Journal, Vol. 7, Issue 1, 2020, 81-97

(C) Universiti Teknologi Malaysia

E-ISSN 2601-002X

DOI: https://doi.org/10.11113/lspi.v7n1.99

\title{
Reading Intervention Practice: Effects of Print and E-Dictionary Use
}

\author{
Zawiah Ghazali \\ Sekolah Menengah Kebangsaan Skudai, Johor Bahru, Johor, Malaysia \\ Hadina Habil \\ Language Academy, Universiti Teknologi Malaysia, 81310 UTM Johor Bahru, Johor, Malaysia \\ Submitted: 10/01/2020. Revised edition: 25/06/2019. Accepted: 28/06/2019. Published online: 30/06/2020
}

\begin{abstract}
This study investigated reading intervention method using print and e-dictionary. In particular, the study examined the effects of print and e-dictionary usage on reading habits and reading comprehension of form sixth students in Johor. Respondents were students with low/limited English proficiency (LEP) in their second semester of sixth form program. Using a mixed method approach, data was gathered quantitatively and qualitatively. Questionnaires were utilised to collect information on students' reading habits and reading attitudes. Reading comprehension test results were obtained from the school MUET panel examination record. The quantitative data was analysed using the SPSS software while the participants' reading comprehension test results were analysed using Excel program. The participants' writing reflection constituted the qualitative data. Findings show that the use of e-dictionary and print dictionary during a reading intervention program affected the reading habits and attitudes of the participants to a certain extent. The use of e-dictionary and print dictionary while reading act as an important factor in assisting LEP students to be better readers. However, there was no significant relationship between the use of e-dictionary and print dictionary and reading comprehension score. Several recommendations on intervention strategies for future research are made from the findings of this study.
\end{abstract}

Keywords: Reading, reading habits, reading comprehension, e-dictionary, dictionary, intervention

\subsection{INTRODUCTION}

The Ministry of Higher Education have made some changes to improve the image of sixth form programme and the quality of its academic standard. These timely changes are needed to improve the image of sixth form programme which started to become unpopular and would sometimes be the last resort for some students to study at pre-university level. Indeed, there was a growing concern regarding the academic quality and language proficiency of some sixth form students. In the 80's

*Correspondence to: Hadina Habil (email: hadina@utm.my) 
and 90 's, sixth form programme was the only pre-university programme but since the establishment of matriculation centres, the better students usually opted for matriculation courses. The recent restructuring of sixth form programme now includes the introduction of school based assessment and the pedagogical approaches in the teaching and learning of Malaysia Higher School Certificate (STPM) subject towards 21st century learning styles (Tingkatan 6 distruktur semula, Berita Harian 2012). The school-based assessment is included to reduce the burden faced by students sitting for the STPM and to make the teaching and learning of STPM subjects more manageable.

Recent changes in the restructuring of sixth form programme and the requirement for certain achievement in the Malaysian University English Test (MUET) for university entry places the responsibility in the hands of MUET teachers to assist low English proficiency (LEP) students in improving their proficiency in English. Effort by MUET teachers is needed to give LEP sixth form students the opportunity to make the biggest improvement they could in their English language proficiency within the limited time available during school hours. It is the aim of this study to examine methods to improve the proficiency level of LEP learners within their school environment.

For many years, the Malaysian University English Test (MUET) results for School A have always shown high percentages of low proficiency achievers of Band 3 and below (MUET Panel School A, 2008-2014). These include a significant percentage of students with the lowest achievement of Band 1 which is now no longer accepted for admission into degree courses at public universities in Malaysia (Jawapan Lisan bagi Pertanyaan Dewan Rakyat, 2014) as was announced in the Malaysian 2015 Budget Report. This dismal performance by sixth form students of School A is an example of similar performances shown by many other schools with sixth form students based on the five-year survey by Malaysian Examination Council (Laporan Kajian Pencapaian Malaysian University English Test (MUET) 2002-2006).

The inclusion of MUET as a subject in sixth form timetable is an effort to prepare students for the MUET examination. Taking into account the presence of study breaks, examination time, school and public holidays in the school calendar, sixth form students at School A actually have much less than the apparent 15 months available to prepare students for the MUET examination from the time they first enrol as lower six students (usually in late April or early May) to the time they, as upper six students, are to sit for the MUET examination in July in the following year. To improve the students' proficiency in English would require teachers to provide a language rich environment and plan effective activities to make the effort viable in the limited time available.

The form sixth students who are still at low/limited English proficiency (LEP) level after their secondary education are at a disadvantage even if they choose not to further their studies but to enter the job market early after their sixth form public examination. This is because an excellent command in English is one of the main criteria that employers in Malaysia look for in prospective employees (Zubairi, et al., 2011, Selvaratnam, 2019). It was reported that 80 per cent of the employers surveyed in the study rated English language proficiency as being equally important as or more important than the knowledge and skills associated with the degree of potential employee. Hence, besides the aim of improving students' proficiency in English for academic purposes, something should also be done to improve LEP students' proficiency level to enhance their employability as required by many employers. 
A significant percentage of sixth form students enrolled in SMK A were already in the LEP category based on their Form 5 Sijil Pelajaran Malaysia (SPM) or Malaysian Certificate of Education English result which ranged from P7, P8, or F9 (MUET Panel SMK A, 2014). Since second language acquisition is highly linked to extensive reading (Renandya, et al., 1999), the lack of or very limited reading due to poor reading habits and attitude towards reading English language materials could be a factor that is inherent in these LEP sixth form students. Hence, this study is interested in identifying the present sixth form LEP students' reading habits and attitude towards English language reading materials.

Since reading is allocated the highest percentage of marks in MUET (40 per cent of the weightage), focusing on practising reading and answering comprehension questions provided in the textbooks would be a typical strategy adopted by teachers hoping to give students more chances of doing well in the exam. Unfortunately for sixth form LEP students the length of the passages and the language level of the reading texts contained in most MUET textbooks proved to be quite difficult for them to handle. Many did not score well in reading comprehension tests carried out at school level (MUET Panel, SMK A, 2014-2015). Based on students' feedback in the classroom, many complained that the passages contained too many unknown or unfamiliar words that made comprehension difficult for them. Students lacked some reading skills such as using contextual clues to guess meanings of words because their vocabulary knowledge was at a low word level that was inadequate for use in practising the skill. Efforts therefore were made by MUET teachers in the school to help improve their vocabulary. Up to the time this study was carried out, activities planned by the MUET Panel for the students to aid language acquisition were a word list activity ('Learn a Word a Day') and a scrapbook project (collection of information through reading a subject of interest) for each class. Since reading is known to be a major source of vocabulary acquisition, students need to be encouraged to enrich their vocabulary through reading especially a lot more than what they are currently doing. It was highly possible that students' reading activity especially in English could be very poorly done on their own because they were not achieving the vocabulary level expected of them. Perhaps it was high time that an extensive reading programme be included in the school's MUET Panel strategic plan to get students to read more to aid their English language acquisition amidst the constraints present in the school environment.

Some reading strategies for comprehension of reading texts may be difficult for LEP students. For example, using contextual clues is difficult when an LEP student could only understand less than $95 \%$ of the words contained in a passage (Laufer, 1989). Long passages which are typical features in MUET textbooks can make the reading task even harder and time-consuming for an LEP student. A common practice by language teachers would be to encourage the use of dictionaries among students besides utilizing various other reading skills to help them comprehend the passages.

At School A, the MUET Panel has allocated a set of print dictionaries for classroom use since bringing their own dictionaries would be troublesome for students. It is unknown whether the students in this study were taught how to use dictionaries during their primary and secondary school years. Nevertheless, getting them to start using print dictionaries intensively is believed to be useful in helping them practice the skills and eventually make them become more efficient users of dictionaries and be better assisted in reading. However, that may take more time than anticipated due to possible lack of practice among LEP learners and thus require a lot of effort to develop efficient 
referencing skill through the use of printed dictionaries. With teachers' guidance and the consistent use of the dictionary, these LEP students would hopefully be more skilled in finding the right entry in the dictionary and therefore be better assisted in their reading. It is hoped that the sixth form LEP students would persevere in their effort to ensure that the use of the dictionaries will improve their reading ability.

Since the allocated MUET Panel dictionaries are kept in a resource room, students need to carry them every time the dictionaries are needed in class. Therefore, in practice, the traditional use of bulky print dictionaries in SMK A's sixth form classes can be a very time-consuming and physically draining activity which is not appealing to LEP learners. This could lead to unsatisfactory outcomes for both teachers and students. Alternative ways are needed to make reading lessons with dictionary use less troublesome and more appealing to the students. Therefore, to encourage the use of print dictionary for a reading intervention programme for these students, they could be brought to the resource room where the dictionaries are kept for their reading activity instead of having to carry those dictionaries to the classrooms. However, acknowledging the lack of feasibility of using the resource room for the school due to high demand (too many classes needing its use), students will need to be able to use dictionaries in other ways. Perhaps, instead of using print dictionaries, the use of technology in reading lessons could be the alternative that might help the teachers and students achieve better outcomes from the reading activity they carry out. An e-dictionary is easy to use, accessible, and expandable, in lieu of a traditional printed dictionary as well as providing user engagement and constant integration (Janjić , Poljak and Kocijan, 2019).

The scope of this study was only limited to a small population of 88 arts stream sixth form students at SMK A, Johor, Malaysia. The study only focused on the selected number of students at SMK A, Johor even though there are a number of public secondary schools in the district that offer sixth form education programme. The decision was based on the convenience of implementing the study for the researcher such as to obtain permission from the school administrators and to get the teachers' and students' cooperation to conduct the study as the researcher is one of the two MUET teachers teaching sixth form students at the school. The intervention in the study which was the extensive reading with dictionary use programme was of beneficial input to the school MUET Panel's effort to carry out activities that are believed or proven to work on improving the state of LEP students' proficiency. The convenience and advantage of carrying out the study with the cooperation from a fellow colleague had ensured that any problems faced by the researcher, her colleague or the participants during the intervention period or the stages in the collection of data was quickly addressed and resolved.

The criterion for the categorisation of the participants as low English proficiency learners was based on their English result in the Malaysian Certificate of Education or SPM (Sijil Pelajaran Malaysia) which they sat for at the end of Form 5 although the assessment criteria for SPM and MUET are not compatible. From the researcher's experience teaching sixth form students, students who scored distinction in SPM (those who scored A+, A or A-) sometimes did fall into the category of LEP learners at sixth form level based on their poor performance in school-based examinations and the actual MUET examination. Thus, the researcher believes that due to the differences in the 
examination format and answering techniques, a good score in the SPM English subject does not necessarily guarantee a good MUET score.

The materials used for the extensive reading programme in this study were texts that were selected by the researcher and her teaching colleague. This choice of reading material may have limited transferability to the ideal extensive reading contexts where students can simply choose their own print text or e-text materials or go online to locate information which has not been structured or manipulated by a researcher. However, due to the difficulty or the impossibility of selecting the ideal reading material with $i+1$ content (where $i$ is the learner's current stage of development according to Krashen (1983)) that could cater to the needs of all readers in the group being studied, the researcher decided to follow the rule of thumb by simply obtaining any material deemed appropriate for the students regardless of whether the material is at an $i+1$ or even an i- 2 criteria as suggested by Renandya and Jacobs (2002).

The study materials are selected by the researcher and her colleague. Students are not given the freedom to select their own materials for the study as there was concern that the LEP students might have the tendency to select 'easy to read' English language materials which might not be challenging enough for them and therefore would not improve their language acquisition. In a study by Abdullah et al. (2012) on UiTM Perak's students involved in a reading for pleasure project, students were found to improve the amount of reading they did but not their reading comprehension. The explanation given was that the amount of reading was not a predictor of reading comprehension as the students might have selected articles that were below their competency level and therefore might not have required them to employ the reading strategies that they were trained to use in their reading at the beginning of the project. In the project, the students were given the freedom to read any reading materials of their choice. Therefore, it was the researcher's belief that to give LEP sixth form students the freedom to select their own reading materials would not be a good strategy to ensure that they use the dictionary as a reading comprehension tool when reading the materials for this study.

The findings also informed the school administrators of the need to ensure that the school facilities such as the school internet server and computer laboratory and the resources for teaching and learning towards achieving 21 st century teaching and learning style through the use of internet resources such as e-dictionaries must be made available to the whole school. Findings from this study too could be of use to other English teachers teaching other forms in the school as a basis for future action research projects to improve or to address their own problems regarding students' English Language proficiency.

Findings on the reading habits and attitudes among the learners in this study helped shed some light on the possible problem afflicting their second language acquisition of English. Krashen (1993) stated that through reading, learners develop a good writing style, an adequate vocabulary, and advanced grammar and become excellent speller; a reader with good reading habit and attitude will then keep on improving his/her language proficiency until adulthood. Hence reading is an essential tool for lifelong learning for all learners (Pandian, 1997). Kirsch and Guthrie (1984) who studied adult readers found that reading contributes significantly to job success, career development, and ability to respond to change. Pandian (1997) who carried out a survey in Malaysia found that 80.1\% of 674 undergraduates and $86 \%$ of 975 high school students were reluctant readers of English language materials. According to Pandian (1997) some of the factors which contribute to poor reading habit in 
English among Malaysian youths are school related. This included attending schools with little variety or too few materials in English and had teachers who do not encourage students to read. An identification of the reading habits and attitudes toward reading English language materials among the sixth form students in this study managed to inform subject teachers and school authorities of possible reading problems among their students that the school could take on and work out solutions within the capacity of the school.

This study could enlighten sixth form teachers and other interested parties on the effects of using both print and e-dictionaries in a reading programme on students' reading comprehension. The researcher believed that the proper use of technology might be of assistance in alleviating the problems faced by those using the traditional methods. Even though it was not conclusive from this study that technology use was found to be the better strategy as anticipated by the researcher, sixth form teachers were nevertheless informed of the need to incorporate such assistive technology use in their classroom reading activities because interview with teachers revealed that its use seemed to be providing the similar positive effects shown by the use of the traditional method (use of print dictionary). School authorities would therefore need to ensure that access to the internet via the school server to enable access to the e-dictionaries is made available to all teachers and students for activities carried out during school hours and not just accessible at a few locations in the school compound. This is especially important for the school to do because not all students can afford mobile devices. The facilities already provided for the school must be made available for utilization by the less affluent students in the school in order for them to gain equal opportunities in education.

\subsection{RELATED WORKS}

This section discusses some of the issues regarding the reading habits and attitude of ESL learners in Malaysia and the need of reading programs to develop and improve language proficiency among students especially the LEP learners. This is followed by a discussion on the teaching of reading and the choice of material appropriate for the purpose of achieving adequate level of reading comprehension among students. Finally, the section ends with a look at the use of dictionaries, both print and e-dictionaries, in teaching reading and the effectiveness of their use in improving reading comprehension among students.

\section{Improving ESL Learners’ Reading Proficiency through Reading Comprehension Support Tools}

Even though reading is an important habit that should be inherent among students who are still studying at tertiary level in Malaysia, studies have shown that many students lack good reading habits or attitude. Two surveys carried out in 1993 and 1997 on the reading culture of Malaysian youths revealed that a high percentage of them fell under the category of 'reluctant readers' in English (Pandian, 1997). The study found that $82 \%$ of 674 undergraduates and $86 \%$ of 975 high school students surveyed were literate who chose not to spend their leisure time reading but preferred 
other forms or recreational activities instead. Based on the responses from both surveys, Pandian suggested that the likely reasons for not reading for leisure in English for most Malaysian youths are generally due to having little exposure to English reading materials in their home and school environment, lack of reading models among teachers and friends, and a negative attitude towards reading in English. A more recent study on polytechnic students from the Engineering and Business department in a selected Polytechnic also found that the students have low interest in reading and did not enjoy reading as much as they enjoyed doing other technology related activities (Annamalai and Muniandy, 2013). A high percentage of the students were found to only spend 2 hours or less on reading per day (1-2 hours 46\%, less than 1 hour $29 \%$ ). Two other surveys on students' reading habits with similar results showcased that tertiary level students spent less time reading than they used to before entering (Sarjit and Rosy, 1999; Rahim, et al., 2007). No study on reading habits of sixth form students has so far been found but based on the surveys already mentioned here, a similar result on their reading habits and attitude will not be totally unexpected.

Since many language teaching practitioners would agree that reading plays a major role in language acquisition, it is right to assume that learners in post- secondary education in Malaysia are at low English proficiency level due to poor reading habits especially of English reading material based on the same reasons as those mentioned in the surveys. It also seems that the NILAM reading programme which was prescribed for all students in primary and secondary schools in Malaysia has failed to inculcate good reading habits among these poor adult readers. The various reasons given were: no time $(70 \%)$; reading is boring $(49.700 \%)$; prefer to play $(38.33 \%)$, books are not interesting $(38.33 \%)$; not enough books $(31.67 \%)$; prefer to watch television and listen to the radio $(29.09 \%)$; tired $(26.88 \%)$; uncomfortable environment/noisy (26.67\%); no opportunity to go to the library (24.39\%); and no interest to read since young (23.64\%) (Program Nilam, 1997). Effective reading activities must therefore be incorporated into the teaching and learning of English in the classroom to assist post-secondary LEP learners in gaining improvement in their proficiency in English. Remedial efforts such as to give them more exposure to English reading materials, creating reading models among teachers and friends, and giving them a positive motivation to change their negative attitude towards reading in English could be workable practice with the aim to help them acquire the muchneeded amount of language.

Students in remedial reading classes at a secondary school in the Philippines showed considerable improvement in their reading skills after undergoing a six-month extensive reading (ER) programme (Renandya, et al., 1999). Learning gains of the group with ER treatment showed a statistically significant degree of better result than those of the traditional group. From their analysis, Renandya, et al., listed 8 characteristics of a successful ER programme: students read a large amount of printed material; students choose what they want to read; students read a variety of materials in terms of topic and genre; materials read is within students' level of comprehension ; students take part in post reading activities; teachers read with their students (serving as role models of good readers); teachers and students keep track of student progress; and teachers provide help and guidance where needed.

Reading intervention among struggling college readers in a study found that there were significant gains in reading rates among students who underwent wide reading (WR) and repeated reading ( $R R)$ programmes (Ari, 2014). The materials used in the programmes were graded selections 
of reading passages to suit the students' instructional reading levels and both groups underwent the same number of session. The students carried out silent sustained reading (SSR) for the same number of sessions. Although not statistically significant, the WR condition was found to be more favourable in increasing the students' silent reading rates by 1.46 times more effectively. According to Ari, if the intervention period were to be long enough it would also facilitate large silent reading rate gains comparable to other similar studies.

A study on the effects of extensive reading programme on fourteen-year-old students in Malaysia showed a positive impact of ER on their comprehension, cloze, and vocabulary tests scores (Kaur, et al. 2008). The students were divided into two groups where one was monitored for weekly scheduled time to do extensive reading while the other was free to do at their own time. Both groups showed improvement in the tests given but the monitored group scored significantly higher. Results from this study only reinforced the same conclusion of other researchers that extensive reading can contribute positively to language proficiency. Kaur et al., suggested that extensive reading should be implemented carefully in schools in Malaysia as a core part of the curriculum and be part of the reading pedagogy where teachers and students play crucial roles in the classrooms. Therefore, to help improve the proficiency of sixth form LEP learners in Malaysia, planning the right reading programme especially one that will engage them in extensive reading activities monitored by teachers would be the most appropriate action plan.

\section{Use of Print and E-dictionaries as Reading Comprehension Support Tool}

To get maximum benefit from their reading, students need to be involved in both extensive and intensive reading but most students will not do a lot of extensive reading by themselves unless they are encouraged to do so by their teachers (Harmer, 2002). Therefore, in an ideal situation, students would be reading on their own but when working with reluctant readers, regular monitoring is recommended (Renandya and Jacobs, 2002). Monitoring, according to Renandya and Jacobs (2002), should be seen as a way of displaying students' progress and motivating students. Positive outcomes from such monitoring can be seen in the study by Kaur et al., (2008). The reading group being monitored during the programme outperformed the one which was not.

Hunt and Beglar (2002) are of the opinion that widely-varied activities and exercises for enabling vocabulary learning among learners will require planning from teachers to incorporate the incidental, intentional, and independent approaches into their language programme. The teachers and the programme should emphasize on those activities that have taken into consideration the learners' level and educational goals. Hunt and Beglar believed that for learners who are still learning the 3000 most common first words, the emphasis should be on the direct teaching of vocabulary. Only after the learners' vocabulary has expanded in size and depth should the emphasis be turned on utilising the extensive reading and independent strategies. Hence, for low proficiency ESL learners, direct teaching will be the main strategy to get them to improve their proficiency level.

The teaching of reading is a complex matter because of the presence of various variables that impact the degree of success of reading instructions (Grabe, 2004). Students' proficiency, age, L1/L2 relations, motivation, cognitive processing factors, teacher factors, curriculum and materials 
resources, instructional setting, and institutional factors are some of the obvious variables that made the process of straightforward connection between research and instructional practices in reading too complex. Using his review of reading theory, research, and assessment, Grabe developed a set of 10 instructional implications for second language reading: ensure word recognition fluency; emphasize vocabulary learning and create a vocabulary rich environment; activate background knowledge in appropriate ways; ensure effective language knowledge and general comprehension skills; teach text structures and discourse organization; promote the strategic reader rather than teach individual strategies; build reading fluency and rate; promote extensive reading; develop intrinsic motivation for reading; and plan a coherent curriculum for students' learning. The goals, except for the last one in the list, are suggested as component abilities of learners that need to be developed for effective reading comprehension based on students' needs, institutional expectations, and resource constraints. The decision of which factors to be emphasized depends on the local context and goals, and the relevance and persuasiveness of supporting research in reading.

Textbook use is thought to be the key in most language programme because it can serve as the basis for language input in the classroom (Richards, 2001). The availability of ministry prescribed textbooks in Malaysia for primary and secondary students under a textbook loan scheme (that is given to all students in Malaysia since 2008 regardless of their socio-economic status) (Skim Pinjaman Buku Teks (SPBT), 2014) seems to make textbook use a norm at all government funded schools. To textbook users, textbooks help to provide structure and syllabus for systematic planning of a programme and standardise instructions to ensure students in different classes (or schools) receive similar contents and therefore can be tested in the same way (Richards, 2001). For sixth form programme in most schools in Malaysia, the use of MUET textbooks that are readily available in the market would then be a common practice among teachers and students. An example of a typical MUET textbook content is to focus on activities and exercises that will help students familiarize themselves with the format of the MUET examination papers 800/1 (listening), 800/2 (speaking), 800/3 (reading), and 800/4 (writing) by focusing on developing the skills required to handle the tasks for each paper (Kaur and Jonas, 2014). The passages for reading are therefore those of similar length and language level to those found in MUET reading papers.

The language level in MUET textbooks may be suitable for use by proficient students but may not be so for LEP learners. Based on the feedback given by MUET examiners on candidates who were found to be limited users, it is revealed that the level of English among LEP learners in Malaysia is way below their expected level of having learned English formally for 11 years (STPM and MUET Examination Report, 2013). According to Krashen's comprehensible input theory, language acquisition will only proceed if the learner understands messages in the second language utilizing structures that is not yet acquired i.e. the input that contains $i+1$ content where $i$ is the learner's current stage of development (Krashen, 1983). It should be emphasized that even though teaching must be matched to the learners' current knowledge, some course books used in teaching are not in touch with the state of this knowledge and hence will not be effective (Prabhu, 1989; Richards, 2001). Remedial effort must be taken to bridge the big gap between LEP students' language level and that of the textbook or in other words, to improve their proficiency to the level that the content and language level of the textbook is at an $\mathrm{i}+1$ for them. This implies that sixth form LEP students and 
their teachers need to do more than simply rely on the content provided by the sixth form textbooks available in the market to help improve the students' English proficiency through reading.

An effective teaching should include tasks which direct the learner's attention to the words (targeted for instruction and require elaboration of the words) such as the use of dictionaries to look up the (target) words in the course of a reading assignment (Laufer, 2000). L2 learners have difficulty in understanding a text without referring to a dictionary because their vocabulary is very limited (Hamilton, 2012). A dictionary is useful whether used electronically, on-line, or in print form because

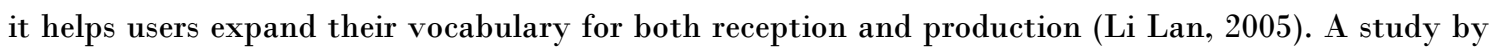
Knight (1994, cited in Laufer, 2000) compared the effect of CALL dictionary lookup with guessing words from context and found that students who used a dictionary learnt more words and achieved higher reading comprehension scores.

E-dictionaries which may either be online, embedded in a portable device, or available as an app on a mobile phone are often found to be better than paper dictionaries (Laufer, 2000). $70 \%$ of students interviewed at Hong Kong Polytechnic University in a study by Li Lan (2005) were also found to favour e-dictionaries more than the traditional paper (print) dictionaries. One obvious reason often reported for not favouring print dictionary use is because of the disruption to the flow of reading due to the time required to flick through the pages to look up for words (Laufer, 2000). The ease and speed of using an e-dictionary may provide the solution to the problem faced by print dictionary users and may contribute to more fluent reading (Laufer, 2000). The Hong Kong study seems to encourage the use of e-dictionaries more than the print version. It was then the interest of this study to look at and compare the effects of both paper and e-dictionaries use by sixth form LEP students in this study on their reading comprehension improvement.

\subsection{THE STUDY}

The design for this study included data collection using questionnaires and test results and a secondary data collection using students' reflections and semi-structured interviews to help the researcher to better understand results from the quantitative data and the issues being studied.

The first phase was at the pre-intervention phase which was before the school's MUET Panel extensive reading programme named READ ME and second phase was at the post-intervention phase which was after the programme was completed. Though initially planned to begin in January, the programme could only start in February due to several changes in the classes' timetables and the allocation of MUET teachers to the four classes in the first month of school.

The extensive reading programme was carried out for twelve weeks from February to May with some interruptions in the flow of the programme due to public holidays, school breaks, and examination weeks. The researcher and a teaching colleague handed over the questionnaires to all participating students and all responded and returned all questionnaires to the researcher. The participants also sat for the Reading (Paper 3) Comprehension Tests administered to them. Two tests were given before the intervention (Test 1 and Test 2), one was given nearing the end of the 
intervention, and another was given two weeks after the extensive reading programme. After the intervention, students were also asked to write their reflections.

\subsection{RESULTS}

The following Tables 1.0, 2.0, and 3.0 summarize the demographic information of the respondents. Table 1.0 gives the overall information while Tables 2.0 and 3.0 depict the statistics of students who used e-dictionary and print dictionary respectively.

Table 1.0 Demographics of participants (overall)

\begin{tabular}{llll}
\hline Race & Male & Female & Total \\
\hline Malay & 8 & 23 & 31 \\
Chinese & 22 & 11 & 33 \\
Indian & 3 & 19 & 22 \\
Others & 1 & 1 & 2 \\
Total & 34 & 54 & 88 \\
\hline
\end{tabular}

Table 2.0 Demographics of e-dictionary users

\begin{tabular}{llllll}
\hline Race & Male & \multicolumn{2}{c}{ Female } & Total \\
\hline & Economy & History & Economy & History & \\
Malay & 0 & 2 & 5 & 5 & 12 \\
Chinese & 13 & 2 & 8 & 2 & 25 \\
Indian & 0 & 0 & 3 & 3 & 6 \\
Others & 0 & 0 & 1 & 0 & 1 \\
Total & 13 & 4 & 17 & 10 & 44 \\
\hline
\end{tabular}

Table 3.0 Demographics of print-dictionary users

\begin{tabular}{llllll}
\hline Race & Male & \multicolumn{2}{c}{ Female } & Total \\
\hline & Economy & History & Economy & History & \\
Malay & 1 & 5 & 3 & 10 & 19 \\
Chinese & 7 & 0 & 1 & 0 & 8 \\
Indian & 1 & 2 & 3 & 10 & 16 \\
Others & 0 & 1 & 0 & 0 & 1 \\
Total & 9 & 8 & 7 & 20 & 44 \\
\hline
\end{tabular}

Table 4.0 lists the types of materials that the students read regardless of language in terms of median and mean. This is to show students' reading habit. 
Table 4.0 Types of reading materials read by the participants in general (regardless of language) and frequency of reading

\begin{tabular}{lll}
\hline Reading Materials & Median & Mean \\
\hline Website & 5 & 4.4545 \\
Academic & 4 & 3.7386 \\
Newspapers & 4 & 3.8636 \\
Magazines & 3 & 2.7841 \\
Comics & 3 & 2.6818 \\
Novels & 2 & 2.4886 \\
Journals & 2 & 2.4091 \\
Others & 1 & 1.0341 \\
\hline
\end{tabular}

The result that is shown in Table 4.0 indicates that in general sixth form students of SMK A had the tendency to spend their time reading materials on websites every day (median $=5$ ). They also tend to spend a few times in a week (median $=4$ ) to read academic books and newspapers. Students had the tendency to spend a few times in a month (median $=3$ ) to read magazines and comics. Only a few times in a year (median $=2$ ) was spent to read novels and journals. The least tendency was to spend time less than once a year $($ median $=1)$ reading other materials such as religious books as cited by one participant.

Table 5.0 Types of reading materials in English read by the participants and the reading frequency

\begin{tabular}{lll}
\hline Reading Materials & Median & Mean \\
\hline Website & 4 & 3.7386 \\
Academic & 3 & 2.8750 \\
Newspapers & 2 & 2.6250 \\
Magazines & 2 & 2.3068 \\
Comics & 2 & 2.2727 \\
Novels & 2 & 2.0568 \\
Journals & 1 & 1.6136 \\
Others & 1 & 1.0000 \\
\hline
\end{tabular}

The result that is shown in Table 5.0 indicates that when it comes to reading in English, sixth form students of SMK A had the tendency to spend their time reading English materials on websites a few times in a week (median $=4)$. They only spent a few times a month (median $=3$ ) to read academic books and newspapers in English. Only a few times in a year (median $=2$ ) was spent to read magazines, comics, novels and journals in English. The least time spent was less than once a year (median $=1$ ) reading other materials in English (no example cited by any participant). Therefore, compared to reading in general, the sixth form students of SMK A tended to spend much less time reading materials in English. 
Table 6.0 Types of reading materials in English read by e-dictionary and print dictionary users and frequency of reading before (pre) and after (post) the intervention

\begin{tabular}{|c|c|c|c|c|c|}
\hline & & \multicolumn{2}{|c|}{ E-dictionary users } & \multicolumn{2}{|c|}{ Print-dictionary users } \\
\hline & & Pre & Post & Pre & Post \\
\hline Academic & $\begin{array}{l}\text { Median } \\
\text { (Mean) }\end{array}$ & $\begin{array}{l}3 \\
(3.1591)\end{array}$ & $\begin{array}{l}3 \\
(3.1364)\end{array}$ & $\begin{array}{l}3 \\
(2.9773)\end{array}$ & $\begin{array}{l}3 \\
(3.1818)\end{array}$ \\
\hline Newspapers & $\begin{array}{l}\text { Median } \\
\text { (Mean) }\end{array}$ & $\begin{array}{l}2.5 \\
(2.4091)\end{array}$ & $\begin{array}{l}3 \\
(2.5227)\end{array}$ & $\begin{array}{l}3 \\
(2.8409)\end{array}$ & $\begin{array}{l}3 \\
(2.8636)\end{array}$ \\
\hline Magazines & $\begin{array}{l}\text { Median } \\
\text { (Mean) }\end{array}$ & $\begin{array}{l}2 \\
(2.1818)\end{array}$ & $\begin{array}{l}2 \\
(2.4773)\end{array}$ & $\begin{array}{l}2.5 \\
(2.4318)\end{array}$ & $\begin{array}{l}2 \\
(2.3182)\end{array}$ \\
\hline Novels & $\begin{array}{l}\text { Median } \\
\text { (Mean) }\end{array}$ & $\begin{array}{l}2 \\
(2.1136)\end{array}$ & $\begin{array}{l}2 \\
(2.1136)\end{array}$ & $\begin{array}{l}2 \\
(2.0000)\end{array}$ & $\begin{array}{l}2 \\
(2.1364)\end{array}$ \\
\hline Website & $\begin{array}{l}\text { Median } \\
\text { (Mean) }\end{array}$ & $\begin{array}{l}4 \\
(3.7273)\end{array}$ & $\begin{array}{l}4 \\
(3.9091)\end{array}$ & $\begin{array}{l}4 \\
(3.7500)\end{array}$ & $\begin{array}{l}4 \\
(4.1136)\end{array}$ \\
\hline Journals & $\begin{array}{l}\text { Median } \\
\text { (Mean) }\end{array}$ & $\begin{array}{l}1 \\
(1.6136)\end{array}$ & $\begin{array}{l}2 \\
(2.0000)\end{array}$ & $\begin{array}{l}1 \\
(1.6136)\end{array}$ & $\begin{array}{l}2 \\
(2.1818)\end{array}$ \\
\hline Comics & $\begin{array}{l}\text { Median } \\
\text { (Mean) }\end{array}$ & $\begin{array}{l}2 \\
(2.2727)\end{array}$ & $\begin{array}{l}2 \\
(2.2727)\end{array}$ & $\begin{array}{l}2 \\
(2.2727)\end{array}$ & $\begin{array}{l}2 \\
(2.1364)\end{array}$ \\
\hline Others & $\begin{array}{l}\text { Median } \\
\text { (Mean) }\end{array}$ & $\begin{array}{l}1 \\
(1.0000)\end{array}$ & $\begin{array}{l}3 \\
(2.8182)\end{array}$ & $\begin{array}{l}1 \\
(1.0000)\end{array}$ & $\begin{array}{l}3 \\
(2.9091)\end{array}$ \\
\hline
\end{tabular}

The result in Table 6.0 indicates that after the intervention, some changes occurred in the time spent on some reading materials in English. Both groups of dictionary users showed increased time spent in reading journals and other materials (such as story books as cited by a few participants) from less than once a year (median $=1$ ) to a few times in a year (median $=2$ ). Based on students' reflections, reading subject-related journals in English was done for completing their assignments on subjects such as General Studies and Business Studies. Increased time spent in reading story books in English is cited by many as due to the extensive reading programme READ ME which is part of the intervention. The time spent on reading other materials in English showed no difference in overall tendency.

Table 7.0 shows the result of the analysis of the participants purpose of surfing the internet. The data was collected in order to see what type of activity that students preferred when they surf the internet.

Table 7.0 Purpose of surfing the internet

\begin{tabular}{ll}
\hline Activities & Percentage (\%) \\
\hline Surfing the internet & 47.25 \\
Listening to music & 31.87 \\
Watching movies & 15.38 \\
Reading & 3.297 \\
Others & 2.198 \\
\hline
\end{tabular}


Based on Table 7.0, only a small percentage $(3.297 \%)$ of students chose reading as a preferred leisure time activity. Hence it can be assumed that most sixth form students of SMK A did not prefer reading during their free time but would choose to do other activities instead. The result shows that high percentages of students preferred surfing the internet $(47.25 \%)$ and listening to music $(31.87 \%)$ as their leisure time activities.

Surfing the internet however may involve reading which may not be as intensive as reading per se but would still contribute to some form of reading and comprehension activity. Based on the information given by students from their reflections, among the reasons cited for surfing the internet are to read the news in general and also to read about the latest development in people's life (friends or families) via Facebook. Some students also cited reading materials from websites. This is consistent with the result shown in Table 4.0 that students chose websites as the type of reading materials most read by them. Hence, even though reading is listed as the least preferred activity during leisure time (as a response to the questionnaire), other forms of reading would still take place in other activities done by students such as in surfing the internet through reading for information or for pleasure.

The participants in this study were sixth form students of SMK A, Johor Bahru, who were found to spend most of their time reading materials contained in websites. Based on what students had reported, this activity was done on a daily basis (see Table 4.0) and this is consistent with their most preferred leisure time activity which is surfing the internet (see Table 4.0). Reading website materials such as online journals was mainly for the purpose of finding information to help them complete their assignments. Reading academic materials and newspapers were also for the purpose of completing assignments and taking part in classroom activities such as discussion on issues. Hence, based on this finding, the students tended to read for academic purpose more than reading for pleasure.

Of this, much less time was involved in reading English texts or materials. After the intervention, only an increase in the time spent reading English journals and other English materials (e.g. story books during READ ME programme) were observed. Nevertheless, there is an indication that there was a very slight shift towards spending more time in reading in English among the participants with the increase in the mean (from 1.7273 to 2.2045 among the e-dictionary users and from 1.8864 to 2.2045 among the print-dictionary users). Perhaps with a longer time period and under better conditions, the change or a more significant increase in the time spent on reading English materials could actually materialise after the intervention,

One limitation of the study is that this study shows that a period of twelve weeks of reading intervention is not sufficient for any significant change to occur in the participants' habits in reading in English. The condition under which the reading programme was implemented was also not conducive to achieve the desired changes in reading habit for reading materials in English because STPM coursework for two subjects (Bahasa Melayu and Pengajian Am) was given for this second semester (January to May). The students were found to be busy with their academic work and were mostly only reading English materials for other than academic purpose during the extensive reading programme. Thus, the researcher is aware that choosing a less busy semester which is the first semester (June to October) when the participants were in lower six with no coursework would have been be a better condition for a possibly better outcome from the intervention. With no coursework it 
could be possible that students would be more willing to make the effort to spend more time reading materials in English because these LEP students were aware that they needed to improve their proficiency in English in order to do well in the MUET examination.

\subsection{CONCLUSION}

From the analyses and the summary of findings, it was found that the time spent reading English journals and other English reading materials has increased. Thus, it can be concluded that the use of e-dictionaries and print-dictionaries in the intervention programme (extensive reading programme READ ME) has made some effects in the reading habits and the reading attitudes of the participants in the study. However, it remains inconclusive to determine which type of dictionary use gives more or better effects on the positive changes in reading habits or attitudes. The effects of the different types of dictionary use by the participants on their reading comprehension also could not be ascertained because the data available was insufficient to provide any lead to any form of relationship between the use and the reading comprehension test result. Nevertheless, it is recommended that the right use of print dictionary and e-dictionary which brings positive effects to the reading habits, reading attitudes and appeared to also bring positive effects to reading comprehension of their users in the long run should be taught to LEP students. This is to ensure that they are skillful in using them which would eventually lead to effective use in the classroom.

\section{Acknowledgment}

The researcher would like to thank SMK A for the cooperation and assistance rendered during the data collection period.

\section{REFERENCES}

Abdullah, S., Rahim, P. R. M. A.,Setia, R., Mohamad, R., Ghazali, N., Sabapathy, E., Nair, G. K. S., Muniandy,M. K., Theethappan, R., Hassan, W. A. W., and Hassan, N. S. I. C. 2012. Reading for Pleasure as a Means of Improving Reading Comprehension Skills. Asian Social Science. 8(13). Canadian Centre of Science and Education. Retrieved November 14, 2014, from file://C:/Users/user/Downloads/21670-71424-1-SM.pdf.

Annamalai, S. and Muniandy, B. 2013. Reading Habit and Attitude among Malaysian Polytechnic Students. International Online Journal of Educational Sciences. 5(1): 32-41. Retrieved November 3, 2014, from http://www.iojes.net/userfiles/article/iojes_946.pdf.

Ari, O. 2014. Fluency Gains in Struggling College Readers from Wide Reading and Repeated Readings. Reading Psychology. DOI:10.1080/02702711.2013.864361. Retrieved November 3, 
2014, from http://dx.doi.org/10.1080/02702711.2013.864361.

Grabe, W. 2004. Research on Teaching Reading. Annual Review of Applied Linguistics. 24: 44-69. Cambridge University Press.

Hamdi, C. 2015. The Effects of Electronic Dictionary Use on Reading Comprehension and Vocabulary Retention of EFL Students. Arab World English Journal. 180-191.

Hamilton, H. 2012. The Efficacy of Dictionary Use While Reading for Learning New Words. American Annals of the Deaf. 157(4). Retrieved November 30, 2014, from http://files.eric.ed.gov/fulltext/ED535143.pdf.

Harmer, J. 2002. The Practice of English Language Teaching. Third Edition. England. Pearson Education Limited.

Hunt, A. and Beglar, D. 2002. Current Research and Practice in Teaching Vocabulary. Methodology in Current Practice. 11th Printing. 2008. Cambridge University Press.

Jawapan Lisan bagi Pertanyaan Dewan Rakyat. 2014. Retrieved November 1, 2014, from http:/www.parlimen.gov.my/files/hindex/pdf/DR-15102014.pdf.

Janjić , M., Poljak, D. and Kocijan. 2019. Proceedings of e Lex 2020. The Good, the Bad and the Ugly. 270-290.

Kaur, H. and Jonas, F. 2014. Effective Practice MUET. Shah Alam: Oxford-Fajar.

Kaur, N., Awang, Z. and Abdullah, K. I. 2008. The Effects of Extensive Reading on Language Proficiency and Motivation to Read on Fourteen-Year-Old Students in Malaysia. Retrieved October 31, 2014, from http://eprints.utm.my/7887/1/EDUPRES_(F1)_12.pdf.

Kirsch, I. S. and Guthrie, J. T. 1984. Adult Reading Practices for Work and Leisure. Adult Education Quarterly. 34(4): 231-232

Knight, S. 1994. Dictionary Use While Reading: The Effects on Comprehension and Vocabulary Acquisition for Students of Different Verbal Abilities. The Modern Language Journal. 78(3): 285-299.

Krashen, S. D. 1983. The Din in the Head, Input and Language Acquisition Device. Foreign Language Annals, 1983 - Wiley Online Library. Retrieved November 12, 2014, from http://web.pdx.edu/ fischerw/courses/advanced/methods_docs/pdf_doc/wbf_collection/06010650/0646_FLA83_Krashen_D.PDF.

Krashen, S. D. 1993. The Power of Reading. Englewood, CO: Libraries Unlimited.

Laporan Kajian Pencapaian Malaysian Unversiti English Test (MUET) 2002-2006. Majlis Peperiksaan Malaysia.

Laporan Peperiksaan STPM dan MUET (2013). November 2013 MUET (800). Majlis Peperiksaan Malaysia. Penerbitan Pelangi Sdn Bhd.

Laufer, B and Hill, M. 2000. What Lexical Information Do L2 Learners Select in a CALL Dictionary and How Does It Affect Word Retention? Language Learning and Technology. 3(2): 58-76.

Laufer, B. 1989. What Percentage of Text Lexis is Essential for Comprehension? In Lauren, C. and Nordman, M. (Eds). In Special Language: From Humans Thinking to Thinking Machine (pp. 316-323). Clevdon, Avon: Multilingual Matters.

Li Lan. 2005. The Growing Prosperity of On-Line Dictionaries. English Today, null. 16-21. Retrieved 
http://journals.cambridge.org.ezproxy.psz.utm.my/action/displayFulltext?type $=1$ andfid $=317966$ andjid $=E N G$ andvolumeId $=21$ andissueId=03andaid $=317965$ andbody $\mathrm{I}$ $\mathrm{d}=$ andmembershipNumber $=$ andsocietyETOCSession $=$.

Pandian, A. 1997. Literacy in Postcolonial Malaysia. Journal of Adolescent and Adult Literacy. 40(5): Feb. 1997.

Prabhu, N. S. 1989. Materials as Support: Materials as Constraint. Guidelines. 11(1): 66-74.

Program Nilam, 1997. Konsep dan Panduan Pelaksanaan di Sekolah. Bahagian Teknologi Pendidikan, Kementerian Pelajaran Malaysia.

Rahim, P. R. M. A., Abdullah, S., and Has, S. M. 2007. A Survey in Reading Habits in UiTM Perak, Paper Presented at the 5th UiTMT Academic Conference, Terengganu Equestrian Resort.

Renandya, W. A. and Jacobs, G. M., 2002. Extensive Reading: Why Aren't We All Doing It?" In Jack C. Richards and Willy A. Renandya (Eds). Methodology in Language Teaching. An Anthology of Current Practice. 1st ed. Cambridge: Cambridge University Press. 295-302.

Renandya, W. A., Rajan, B. R. S., and Jacobs, G. M., 1999. Extensive Reading with Adult Learners of English as a Second Language. In T. Hedge, N. Andon and M. Dewey (Eds). English Language Teaching: Major Trends in Education, Vol IV. London, Routledge, 2009 Retrieved November $14, \quad 2014, \quad$ from https://www.academia.edu/2502977/Extensive_reading_with_adult_learners_ of_English_as_a_second_language.

Richards, J. C. 2001. The Role of Textbooks in a Language Program. New Routes.

Sarjit, K. and Rosy, T. 1999. The English Reading Habits of ELLS Students in University Science Malaysia. Paper Presented at the Sixth International Literacy and Education Research Network Conference, Bayview Beach Resort, Penang, Malaysia.

Selvaratnam, Viswanathan. 2019. Malaysia's National Language Policy and Graduate Employability. International Higher Education. Number 96: 16-18.

Skim Pinjaman Buku Teks (SPBT). 2014. Portal Rasmi Kementerian Pendidikan Malaysia. Retrieved November 14, 2014, from http://www.moe.gov.my/v/Skim-Pinjaman-Buku-Teks.

STPM and MUET Examination Report 2013. Majlis Peperiksaan Malaysia. Penerbitan Pelangi. 2014.

Tabata-Sandom, M. M. 2016. How do Learners of Japanese Read Texts When They Use Online Popup Dictionaries? Reading Matrix: An International Online Journal. 16(2): 98-109.

Tingkatan 6 distruktur semula. Berita Harian. July 6, 2012.

Zubairi, A. M., Sarudin, I., Nordi, M. S., and Ahmad, T. B. T. 2011. English Language Competency for Entry-level Employment: A Market Research on Industrial Needs. Prestariang Systems. 2011. Retrieved November $27, \quad$ from file://C:/Users/user/Downloads/English_Competency_for_Entry-_ Level_Employment__Market_Research_on_Industrial_Needs_20110412.pdf. 